\title{
Isolation of Liver Oval Cells from Hamsters Treated with Diethylnitrosamine and 2-Acetyl Aminofluorene
}

\author{
Byung-Il YOON, Jae-Hyun LEE'), Kyung-Whan JOO ${ }^{3)}$, Yong-Soon LEE ${ }^{1)}$ and Dae-Yong KIM* \\ Departments of Veterinary Pathology and ${ }^{1)}$ Public Health, College of Veterinary Medicine, Seoul National University, Suwon 441-744, \\ ${ }^{2)}$ Experimental Pathology Laboratory, Korea Cancer Hospital, Seoul, and ${ }^{3)}$ Department of Parasitology, College of Medicine, Korea \\ University, Seoul, Korea
}

(Received 30 August 1999/Accepted 16 November 1999)

\begin{abstract}
Recently, cholangiocellular carcinoma (CCC) was successfully induced in the hamster by infecting with Clonorchis sinensis following hepatocarcinogen treatment and has been proposed as a suitable model to study the pathogenesis of human CCC. In this hamster model, oval cells are suggested to be cells of origin of CCC. More direct analysis of histogenesis of CCC would become possible if large numbers of highly purified oval cells of hamster origin are obtained. In this study, we describe successful isolation of highly purified oval cells from hamsters. Oval cells were induced by diethylnitrosamine and 2-acetylaminofluorene treatment under choline deficient diet and isolated by centrifugal elutriation method. This isolated cells were highly homogenous in size $(10.9+/-1.1 \mu \mathrm{m}$ in diameter) and had a high nuclear to cytoplasmic ratio, an oval-shaped nucleus and a few cytoplasmic organelles. Immunocytochemically, $85.4+/-1.6 \%, 75.1+/-2.0 \%, 62+/-1.5 \%$ and $25.6+/-2.7 \%$ of the isolated cells were positive for cytokeratin 19, OV-6, albumin and alpha-fetoprotein, respectively, indicating that these cells had phenotypic characteristics of both hepatocytes and bile duct epithelium. The isolated cells were therefore considered to be hamster oval cells.-KEY wORDS: centrifugal elutriation, hamster, isolation, oval cell.
\end{abstract}

J. Vet. Med. Sci. 62(3): 255-261, 2000

Proliferation of a new cell population morphologically defined as oval cells occurs during chemically induced severe liver injury and is among the first cellular changes of early hepatocarcinogenesis $[1,3,4,11,14]$. At the early stage of hepatocarcinogenesis, this population of cells first appears intraportally and then extends into the periportal zone [3, 6, 14]. Electron microscopically, the oval cells have ovoid or irregular shaped nuclei, a high nuclear/ cytoplasmic ratio, and scant cytoplasmic organelles (rare rough endoplasmic reticulum and few round mitochondria) $[12,15,22]$.

Oval cells are considered as facultative bipotential precursor cells that can differentiate into either hepatocytes or biliary cell lineage depending upon environmental condition or regulatory factors $[2,5,7,18]$. Cytochemical and immunocytochemical studies showed that isolated rat oval cells are positive to both hepatocyte markers (alphafetoprotein (AFP) and albumin) and biliary cell markers (gamma-glutamyl transpeptidase (GGT) and cytokeratin 19 (CK19)) [6, 12]. In addition, oval cells are believed to be the cells of origin of hepatocellular carcinoma (HCC) and cholangiocellular carcinoma (CCC) $[8,10,16]$; several studies have shown that transformed rat oval cell lines develop into HCC, CCC, or anaplastic tumor when they are transplanted to syngeneic recipients [20, 21, 23].

High incidence of $\mathrm{CCC}$ has been reported from people living in liver fluke-endemic area [9, 19]. Recently,

* Correspondence to: Kim, D.-Y., Department of Veterinary Pathology, College of Veterinary Medicine, Seoul National University, Suwon, 441-744, Korea. cholangiocarcinogenesis in hamsters by Clonorchis sinensis (CS) infection combined with hepatocarcinogen was established and proposed as a model to study the role and cellular differentiation of oval cell as the possible cells of origin of CCC [10]. Direct analysis of differentiation and plasticity of these cells in the hamster CCC model would become possible if large numbers of highly purified oval cells are obtained.

In this study, we attempted to isolate highly purified oval cells from hamster livers treated with diethylnitrosamine (DEN) and 2-acetylaminofluorene (2-A AF) and fed a choline deficient diet by centrifugal elutriation method and characterized the isolated cells. The cells obtained were confirmed as oval cells electron microscopically, cytochemically and immunocytochemically. Growth characteristic and colony forming ability of the isolated oval cells was also performed.

\section{MATERIALS AND METHODS}

Oval cell induction and histology: Male, Syrian golden hamsters were housed in temperature and humidity controlled rearing system (Daejong Co., Korea) with a 12 $\mathrm{hr}$ dark/light illumination cycle. Hamsters aged 5 to 6 weeks were treated with $0.005 \%$ DEN (Sigma Co., U.S.A.) in drinking water for 2 weeks followed by 1 week recovery period. Then $1 \%$ 2-AAF (Sigma Co., U.S.A.) in corn oil was administered orally at a volume of $0.1 \mathrm{~m} l /$ day for another 2 weeks for oval cell induction. During the fiveweek induction period, a choline deficient diet and water were supplied ad libitum. To confirm oval cell induction, the livers from several hamsters were fixed in $10 \%$ 
phosphate-buffered neutral formalin at the end of induction period, routinely processed and stained with Hematoxylin and Eosin (H\&E) for histological examination.

Isolation and culture of oval cells: Oval cells were isolated as previously described with minor modifications [12]. First, the hamster was anesthetized with ether and the liver was perfused in situ through the portal vein with oxygenated, calcium-free Hank's balanced salt solution at $37^{\circ} \mathrm{C}$ and then with the same perfusion solution supplemented with $0.1 \% \mathrm{wt} / \mathrm{v}$ collagenase type I (Sigma Co., U.S.A.) and calcium. Thereafter, Glisson's capsule was removed and the tissue was minced in $25 \mathrm{~m} l$ of digestion medium (Dulbecco's Modified Eagle's Medium (DMEM) (Gibco, Germany) containing 3\% fetal bovine serum (FBS) (Sigma Co., U.S.A.), 0.1\% collagenase type I, $0.1 \%$ Pronase (Sigma Co., U.S.A.) and $0.004 \%$ DNase (Sigma Co., U.S.A.) and incubated twice each for $20 \mathrm{~min}$ at $37^{\circ} \mathrm{C}$ in a shaking water bath. After each incubation, the supernatant containing the released cells was decanted and filtered through $100 \mu \mathrm{m}$ mesh, and then cold DMEM with $3 \% \mathrm{v} / \mathrm{v}$ FBS was added and centrifuged at $400 \mathrm{~g}$ for $5 \mathrm{~min}$ at $4^{\circ} \mathrm{C}$. The pellet was resuspended in Gey's Balanced Salt Solution (GBSS, Sigma Co., U.S.A.) and centrifuged at 400 $\mathrm{g}$ for $5 \mathrm{~min}$. A density gradient centrifugation in Nycodenz (Sigma Co., U.S.A.) was performed and nonparenchymal cells were obtained. The pelleted cells were resuspended with GBSS in a final volume of $11 \mathrm{ml}$, mixed with $14 \mathrm{ml}$ of the $28.7 \%$ w/v Nycodenz solution, and the surface was covered with $2 \mathrm{~m} l$ of GBSS. After centrifugation at $400 \mathrm{~g}$ for $15 \mathrm{~min}$ at $4^{\circ} \mathrm{C}$, highly enriched nonparenchymal cells of top layer were removed and centrifuged at $400 \mathrm{~g}$ for $5 \mathrm{~min}$ at $4{ }^{\circ} \mathrm{C}$. The pellet was resuspended in $5 \mathrm{~m} l$ of elutriation medium (DMEM containing 0.004\% w/v DNase and 3\% v/ $\mathrm{v}$ FBS). Oval cells were further purified from the nonparenchymal cell suspension by centrifugal elutriation. A JE-5.0 elutriation centrifuge rotor with a Sanderson separation chamber was used in a J6-MI Beckman centrifuge at a speed of $2,500 \mathrm{rpm}$ and at $10^{\circ} \mathrm{C}$. The nonparenchymal cell suspension was loaded into the elutriation system at an initial flow rate of $10 \mathrm{~m} l / \mathrm{min}$. Five fractions were obtained by using flow rates of $15,22,32,35$ and $42 \mathrm{ml} / \mathrm{min}$, respectively. Cells from each fraction were plated in 6 or 24 well plate containing DMEM: Ham's F10 (1:1) supplemented with $10 \% \mathrm{v} / \mathrm{v}$ FBS, $1 \mu \mathrm{g} / \mathrm{ml}$ insulin (Sigma Co., U.S.A.), $0.5 \mu \mathrm{g} / \mathrm{m} l$ hydrocortisone (Sigma Co., U.S.A.) and $1 \% \mathrm{v} / \mathrm{v}$ penicillin/streptomycin (Sigma Co., U.S.A.) and cultured at $37^{\circ} \mathrm{C}$ in a humidified atmosphere of $5 \% \mathrm{CO}_{2}$. The culture medium was changed every $3-4$ days. The cell viability was estimated by trypan blue exclusion method.

Cytochemistry and Immunocytochemistry: Cell smears from freshly isolated cells of the 5 fractions were air dried and fixed in cold acetone for $10 \mathrm{sec}$ and GGT activity staining was performed according to method described by Ruthenberg et al. [13]. For immunocytochemical detection of CK19, OV-6, albumin, and alpha-fetoprotein (AFP), cell smears were fixed in cold methanol for $10 \mathrm{~min}$ and then in cold acetone for $10 \mathrm{sec}$. The fixed cells were then incubated with unlabeled antibodies directed against CK19 (Novocastra, U.S.A. 1:100), OV-6 (a gift from Dr. Sell at Albany Medical College; 1:40), albumin (Biogenex, U.S.A.; 1:100), and AFP (a gift from Dr. Sell; 1:200) at $4^{\circ} \mathrm{C}$ overnight. After washing, the cells were incubated with biotinylated secondary antibodies for $40 \mathrm{~min}$ at $37^{\circ} \mathrm{C}$. The standard avidin-biotin-peroxidase complex (ABC) method was used according to manufacture's protocol (Vector Laboratories, U.S.A.) to demonstrate antigen using 3,3diaminobenzidine as the chromogen. For positive control, rat oval cells isolated by the same protocol used to isolate hamster oval cell were stained. For negative control, primary antibodies were omitted and only buffer used for antibody dilution was applied. In order to determine the percentage of immunoreactivities, approximately 500 cells per slide were counted in each preparation. The counting was performed as quadruplicate and the results were expressed as mean +/- SD.

Transmission electron microscopy: The cell pellets from each fraction were fixed with $2 \%$ glutaraldehyde in Sorenson's buffer. After washing 3 times in $0.01 \mathrm{M}$ phosphate buffer ( $\mathrm{pH} 7.3$ ), the cells were post-fixed in $1 \%$ $\mathrm{OsO}_{4}$ for $30 \mathrm{~min}$, washed 3 times in $0.01 \mathrm{M} \mathrm{PB}$, dehydrated in a graded ethanol series and propylene oxide, and embedded in Epon. Ultrathin sections were stained with uranyl acetate and lead citrate and examined under Philips CM12 transmission electron microscope.

Growth curve and soft agar assay: To determine the growth rate of isolated oval cells, $1 \times 10^{4}$ cells from $32 \mathrm{ml} /$ min fraction were plated in 24-well plate containing standard cell culture medium and counted every 3 days using hemocytometer after trypsinization. The ability of oval cells to form colonies in soft agar was also assayed. Twenty thousands cells in $2 \mathrm{ml}$ of culture medium containing $20 \%$ fetal bovine serum with $0.3 \%$ agar (Difco, U.S.A.) were laid on $1 \mathrm{ml}$ of basal layer of $1 \% \mathrm{wt} / \mathrm{v}$ agar in $35 \mathrm{~mm}$ petri dishes. After 1 week, $0.5 \mathrm{~m} l$ of fresh medium was added and colony formation was determined on 2 week. NIH 3T3 fibroblast cell line served as a positive control.

\section{RESULTS}

Histological examination of the hamster livers treated with DEN and 2-AAF under choline deficient diet showed severe oval cell induction (Fig. 1A, 1B).

Cells from each fraction collected at the flow rate of 15 , $22,32,35$ and $42 \mathrm{ml} / \mathrm{min}$ using centrifugal elutriation procedure were homogenous in their size; the cell size increased gradually in proportion to flow rates (Table 1, Fig. 3A-3D). The fractions were named as fraction 1 to 5 in this order. The cell viability from all fractions was $95 \pm$ $4 \%$. The result of elutriation centrifugation was summarized in Table 1.

Oval cells were identified based on the following criteria: 1) cell diameter within the range of 10 to $15 \mu \mathrm{m} ; 2$ ) immunoreactivities to CK19, OV-6, albumin and AFP; 3) presence of GGT activity; 4) characteristic electron 
Table 1. Cell size, cytochemical and immunocytochemical characteristics of cells from elutriated cell fractions

\begin{tabular}{ccrrcrrr}
\hline Fraction & $\begin{array}{c}\text { Flow rate } \\
(\mathrm{m} / \mathrm{min})\end{array}$ & \multicolumn{1}{c}{$\begin{array}{c}\text { Cell size } \\
(\mu \mathrm{m})\end{array}$} & \multicolumn{1}{c}{$\begin{array}{c}\text { GGT } \\
(\%)\end{array}$} & \multicolumn{1}{c}{$\begin{array}{c}\text { CK19 } \\
(\%)\end{array}$} & \multicolumn{1}{c}{$\begin{array}{c}\text { OV-6 }^{\text {a) }} \\
(\%)\end{array}$} & \multicolumn{1}{c}{$\begin{array}{c}\text { Albumin }^{\text {a) }} \\
(\%)\end{array}$} & \multicolumn{1}{c}{$\begin{array}{c}\text { AFP } \\
(\%)\end{array}$} \\
\hline 1 & 15 & $6.9 \pm 0.9$ & $4.3 \pm 1.0$ & $27.9 \pm 1.5$ & $25.6 \pm 0.9$ & $8.4 \pm 1.3$ & $4.8 \pm 1.4$ \\
2 & 22 & $8.2 \pm 1.0$ & $4.6 \pm 0.6$ & $35.0 \pm 1.3$ & $36.8 \pm 1.4$ & $18.0 \pm 1.9$ & $6.9 \pm 1.4$ \\
3 & 32 & $10.9 \pm 1.1$ & $30.2 \pm 1.7$ & $85.4 \pm 1.6$ & $75.1 \pm 2.0$ & $62.0 \pm 1.5$ & $25.6 \pm 2.7$ \\
4 & 35 & $14.0 \pm 0.8$ & $9.9 \pm 1.3$ & $80.0 \pm 2.0$ & $78.6 \pm 1.2$ & $51.3 \pm 5.0$ & $13.9 \pm 1.6$ \\
5 & 42 & $16.2 \pm 1.3$ & $4.8 \pm 0.8$ & $44.6 \pm 1.3$ & $82.3 \pm 1.5$ & $39.1 \pm 8.5$ & $13.6 \pm 2.1$ \\
\hline
\end{tabular}

a) Approximately 500 cells were counted on each slide preparation, and the percentages of positive cells are shown.

microscopic features. The cells in fraction 3 almost fulfilled these criteria except for the low percentage of GGT-positive cells (Table 1). The average diameter (+/- SD) of cells in fraction 3 was $10.9 \pm 1.1 \mu \mathrm{m}$, and $85.4 \pm 1.6 \%, 75.1 \pm$ $2.0 \%, 62.0 \pm 1.5 \%$ and $25.6 \pm 2.7 \%$ of the cells were positive to CK19, OV-6, albumin and AFP, respectively (Fig. 2B2D, Fig. 3C). However, only $30.2 \pm 1.7 \%$ of the cells had GGT activity (Fig. 2A). According to the previous studies, rat oval cells range from 10 to $15 \mu \mathrm{m}$ in cell diameter and usually have GGT activity and immunoreactivity for albumin [12, 22]. Electron microscopically, the cells in fraction 3 had an irregular or ovoid nucleus with variable amount of condensed chromatin, high nuclear/cytoplasmic ratio, and very few mitochondria or rough endoplasmic reticulum as noted previously in isolated rat oval cells (Fig. 4A). They occasionally had microvilli on the cell surface. The purity of fraction 3 was determined to be $90-95 \%$, suggesting that approximately 9 out of 10 cells elutriated at fraction 3 are oval cells. The remaining 5 to $10 \%$ of the cells were identified as fibroblasts, Ito cells or Kupffer cells as judged by electron microscopy or immunohistochemistry (data not shown).

The cells in fractions 1 and 2 were mostly inflammatory cells and endothelial cells by electron microscopy. The immunoreactivities of cells in these fractions to each antigen was very weak compared to that of cells in fraction 3 . High percentage of the cells in fraction 4 were also positive for CK19 $(80.0 \pm 2.0 \%)$, OV-6 (78.6 $\pm 1.2 \%)$ and albumin $(51.3 \pm 5.0 \%)$. However, fraction 4 consisted of not only primitive but also relatively differentiated oval cells compared to fraction 3. On electron microscopy, cells in fraction 4 were similar to those in fraction 3 but significant number of cells were slightly larger than the latter and had more abundant mitochondria and endoplasmic reticulum (Fig. 4B). Fraction 5 was composed mostly of hepatocytes and bile duct cells as well as oval cells. The hepatocytes had round nuclei with condensed or marginated chromatins and many round, ovoid or dumbbell-shaped mitochondria in their cytoplasm. The bile duct cells characteristically had well developed long microvilli on the cell surface and rich rough endoplasmic reticulum and small round mitochondria in the cytoplasm.

The population doubling time of cells from fraction 3 was $36 \mathrm{hr}$ and reached plateau at 10-13 days since the culture was initiated (data not shown). Cells from fraction 3 did not grow or form colony in soft agar (data not shown).

\section{DISCUSSION}

Small intraportal oval cells which appear in the livers of rats treated with a variety of hepatocarcinogens are suspected to be early progenitor cells for both hepatocytes and bile duct cells as well as cells of origin of HCC and CCC $[2,3,6,7,10,11,16,21,23]$. Human CCC model was established in hamster following dimethylnitorsamine treatment combined with infection of CS metaceracriae [10]. It was proposed from this model that duct forming or ductular oval cells are the precursor of dysplastic ductular cells that finally develop into CCC. Although, this conclusion is speculative, it appears that activation or initiation of oval cells by hepatocarcinogen followed by stimulation of proliferation by CS promotes dysplastic hyperplasia of oval cells and finally leads to development of CCC. However, in order to investigate the histogenesis and the role of CS infection in this model more directly, isolation of a large number of high purity oval cells is essential.

Methods such as isopyknic centrifugation in metrizamide or Percoll gradient and centrifugal elutriation have been used to isolate highly enriched oval cells from nonparenchymal cell suspension of rat $[12,15,18,22]$. Among them centrifugal elutriation has been most successful. In the present study, combination of in situ collagenase perfusion of the liver, collagenase/Pronase digestion of the minced liver tissue, Nycodenz density gradient centrifugation, and centrifugal elutriation was used to obtain pure oval cell fraction from the hamster livers treated with DEN and 2AAF.

Five fractions ranging from 15 to $42 \mathrm{ml} / \mathrm{min}$ were collected and the cells elutriated at fraction 3 mostly satisfied the criteria of oval cells mentioned in the result section. The flow rate of oval cell fraction in our study was lower than that of rat oval cell fraction of Yaswen et al. $(40 \mathrm{ml}$ min) [22] or Pack et al. (39.5 $\mathrm{ml} / \mathrm{min})$ [12]. This discrepancy is probably due to a difference of the chamber used for separation; in our study, Sanderson chamber was used instead of standard chamber. The oval cells isolated from our hamster model were morphologically, 

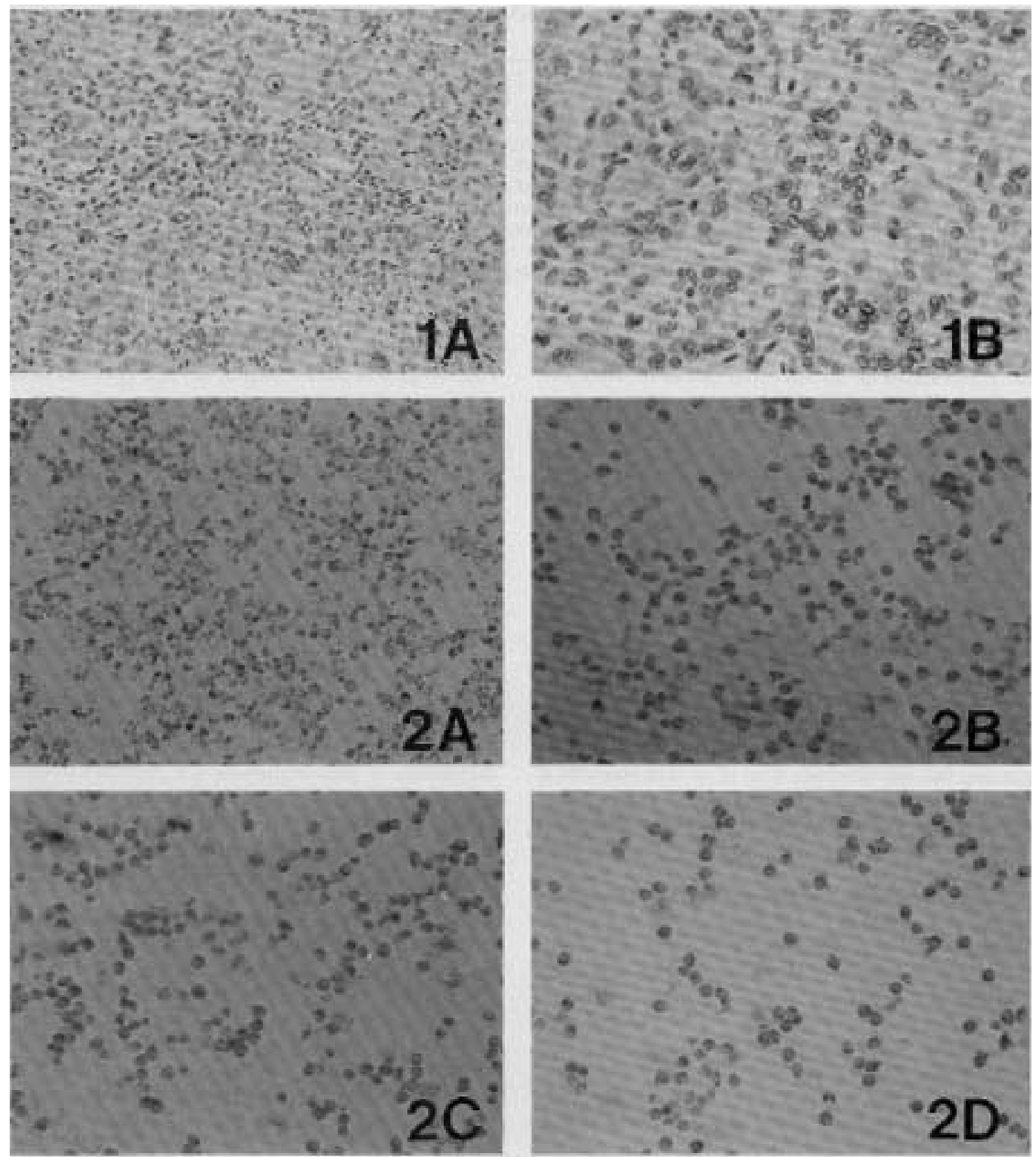

Fig. 1. A; Liver of the hamster administered with $0.005 \% \mathrm{DEN}$ for 2 weeks followed by 1 week recovery period and 2-week 2-AAF administration. Note massive proliferation of oval cells in the portal area. B; higher magnification of Fig. A. H\&E, $\times 200($ A),$\times 400$ (B).

Fig. 2. GGT cytochemical stain (A) or immunocytochemical staining for OV-6 (B), albumin (C) and AFP (D) of cells in fraction 3. ABC method, $\times 400$.

cytochemically and immunohistochemically similar to those of rat oval cells, except relatively low GGT expression rate. Percentage of cells in fraction 3 positive for CK19 and albumin were $85.4 \pm 1.6 \%$ and $62 \pm 1.5 \%$, respectively.
High percentage of cells in fraction 3 was also immunoreactive to OV-6 that has been known as an oval cell marker in rats [3]. The dual expression of both biliary cell and hepatocyte markers is one of the most important 


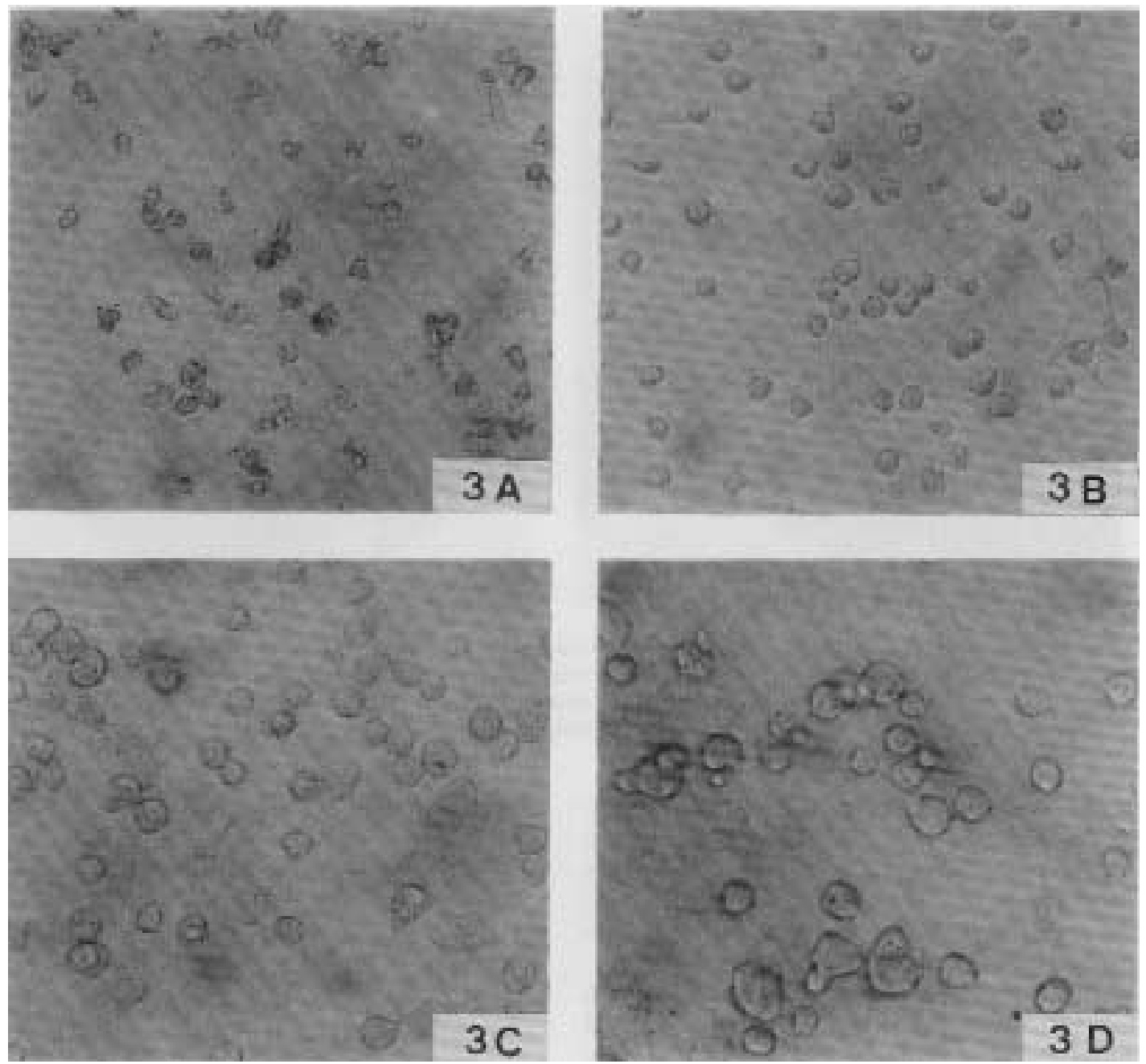

Fig. 3. Cells elutriated at $15 \mathrm{~m} l / \mathrm{min}$ (A), $22 \mathrm{ml} / \mathrm{min}$ (B), $32 \mathrm{ml} / \mathrm{min}$ (C) and $42 \mathrm{ml} / \mathrm{min}$ (D) flow rate. The cells collected from each fraction were homogenous in size which increased gradually in proportion to flow rates. The cells elutriated at $32 \mathrm{ml} / \mathrm{min}$ flow rate (C) mostly satisfy the criteria of oval cells. $\times 200$.

characteristics of oval cells to be distinguished from the hyperplastic bile ductular cells or hepatocytes. Cells elutriated at fraction 4 also showed similar immunoreactivities to those of cells from fraction 3 but it was apparent on electron microscopy that fraction 4 consists of cells in the intermediate stage of differentiation as well as oval cells. These cells were assumed as "transitional cells" or "intermediate cells" that are in the middle stage of maturation to hepatocytes.

GGT expression rate $(30.2 \pm 1.7 \%)$ of the hamster oval cells isolated in this study was lower than that of isolated rat oval cells which are usually about $80-90 \%$ positive [12, $15,22]$. GGT expression has been proposed as a marker for assessing the comparability of oval cell population in rat oval cell isolation because of its high expression [17]. In hamster oval cell isolation, GGT expression was highest in the oval cell fraction although the positive rate was relatively low compared with rat oval cells. It was not clear why GGT expression was low in hamster oval cells isolated in our study. Nevertheless, we can not exclude the possibility that the difference in GGT activity between rat and hamster oval cells was just due to species difference or the different protocol used to induce the oval cells. Yaswen et al. [22] and Pack et al. [12] used choline deficient diet supplemented with $0.1 \%$ ethionine to induce oval cells, while we fed choline deficient diet with DEN and 2-AAF which induce severe damage to parenchymal cells. Therefore, our protocol probably commits the induced oval cells to differentiate toward hepatocyte lineage. The intermediate hepatocyte-like cells present at fraction 4 and 5 support this concept. Cells collected at fraction 4 were rather large and had more mitochondria and rough endoplasmic reticulum in their cytoplasm than the cells in fraction 3 but they were generally smaller than normal hepatocytes in their size (Fig. 


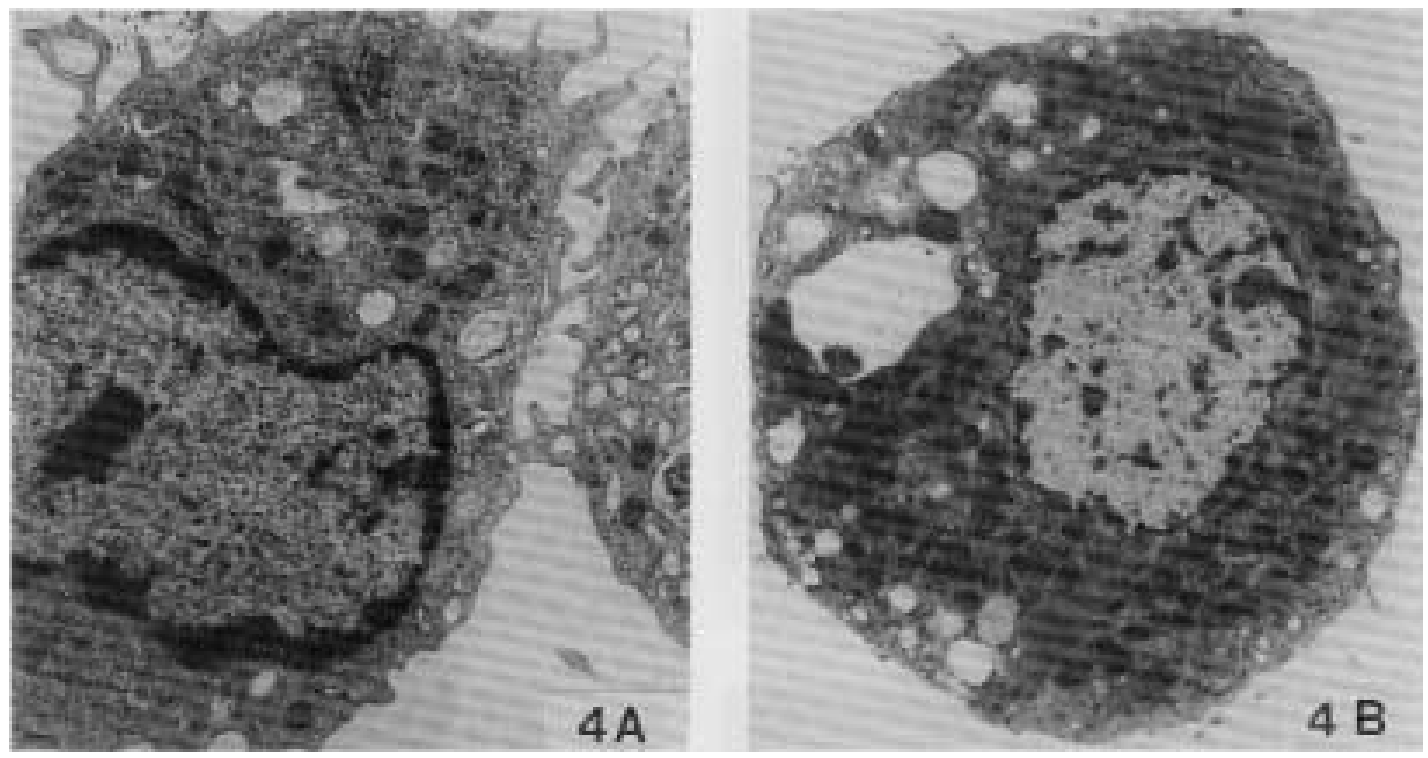

Fig. 4. An electron micrograph of a cell elutriated at $32 \mathrm{ml} / \mathrm{min}$ (A) or $35 \mathrm{ml} / \mathrm{min}$ (B) flow rate. A; Note high nuclear to cytoplasmic ratio, an ovoid shape nucleus, scant cytoplasmic organelles and the presence of surface projections. $B$; Note the increased number of small round or dumbbell-shaped mitochondria and endoplasmic reticulum compared with the cell in Fig. A. Uranyl acetate and lead citrate. $\times 3,600$ (A), $\times 5,200$ (B).

2F). However, according to the histochemical, immunocytochemical and morphological investigations, the small cells present in fraction 3 must be progeny of liver stem cells to have characteristics of both biliary cell lineage and hepatocyte although the cells had a tendency to differentiate into hepatocyte.

The isolated hamster oval cells had no ability to form colonies on soft agar assay. Tumorigenicity of the oval cells is under investigation in syngeneic species or nude mice. Growth curve showed that the doubling time of the oval cells was $36 \mathrm{hr}$ and the plateau period was 13 days.

Two-step hepatocarcinogenesis model using rats have been commonly used to study the pathogenesis of hepatocellular carcinoma, while hamster CCC model has been proposed as a model to study cholangiocarcinogenesis and the relationship between oval cells and CCC. Recently Lee et al. successfully induced undifferentiated and pleomorphic CCC in hamsters by infecting with CS after oval cell induction [10]. Our method reported here was appropriate for isolating oval cells with high purity and viability without significant contamination of even oval cells in different stage of differentiation. The isolation of highly purified viable oval cells from hamster is first reported in this paper and will broaden the study of their developmental plasticity and the role in cholangiocarcinogenesis.

ACKNOWLEDGMENT. The authors wish to acknowledge the financial support of the Korea Research Foundation made in the program year of 1997.

\section{REFERENCES}

1. Anikumar, T. V., Golding, M., Edwards, R. J., Lalani, E-N., Sarraf, E. and Alison, M. 1995. The resistant hepatocyte model of carcinogenesis in the rat: the apparent independent development of oval cell proliferation and early nodules. Carcinogenesis 16: 845-853.

2. Evarts, R. P., Nagy, P. and Nakatsukasa, E. 1989. In vivo differentiation of rat liver oval cells into hepatocytes. Cancer Res. 49: 1541-1547.

3. Evarts, R. P., Nakatsukasa, H., Marsden, E. R., Hsia, C-C, Dunsford, H. A. and Thorgeirsson, S. S. 1990. Cellular and molecular changes in the early stages of chemical hepatocarcinogenesis in the rat. Cancer Res. 50: 3439-3444.

4. Farber, E. 1956. Similarities in the sequences of early histological changes induced in the liver of the rat by ethionine, 2-acetylaminofluorene, and 3-methyl-4-dimethylaminoazobenzene. Cancer Res. 16: 142-149.

5. Germain, L., Blouin, M. and Marceau, N. 1988. Biliary epithelial and hepatocytic cell lineage relationships in embryonic rat liver as determined by the differential expression of cytokeratins, $\alpha$-fetoprotein, albumin, and cell surface-exposed components. Cancer Res. 48: 4909-4918.

6. Germain, L., Goyette, R. and Marceau, N. 1988. Differential cytokeratin and $\alpha$-fetoprotein expression in morphologically distinct epithelial cells emerging at the early stage of rat hepatocarcinogenesis. Cancer Res. 45: 673-681.

7. Germain, L., Noel, M., Gourdeau, H. and Marceau, N. 1988. Promotion of growth and differentiation of rat ductular oval cells in primary culture. Cancer Res. 48: 368-378.

8. Hacker, H. J., Steinberg, P., Toshlov, I., Oesch, F. and Bannasch, P. 1992. Persistence of the cholangiocellular and hepatocellular lesions observed in rats fed a choline-deficient/DL-ethionine-supplemented diet. Carcinogenesis 13: 271-276. 
9. Kirby, G. M., Pelkonen, P., Vatanasapt, V., Camus, A. M., Wild, C. P. and Lang, M. A. 1984. Association of liver fluke (Ptisthorchis viverrini) infestation with increased expression of cytochrome p450 and carcinogen metabolism in male hamster liver. Mol. Carcinog. 11: 81-89.

10. Lee, J. H., Rim, H. J. and Sell, S. 1997. Heterogeneity of the 'oval-cell' response in the hamster liver during cholangiocarcinogenesis following Clonorchis sinensis infection and dimethylnitrosamine treatment. J. Hepatol. 26: 1313-1323.

11. Lemire, H. M., Shiojiri, N. and Fausto, N. 1991. Oval cell proliferation and the origin of small hepatocytes in liver injury induced by D-galactosamine. Am. J. Pathol. 139: 535-552.

12. Pack, R., Heck, R., Dienes, H. P., Oesch, F. and Steinberg, P. 1993. Isolation, biochemical characterization long-term culture, and phenotype modulation of oval cells from carcinogen-fed rats. Exp. Cell. Res. 204: 198-209.

13. Rutenberg, A. M., Kim, H., Fischbein, J. W., Hanker, J. S., Wasserkrug, H. L. and Seligman, A. M. 1969. Histochemical and ultrastructural demonstration of gammaglutamyltranspeptidase activity. J. Histochem. Cytochem. 17: 517-526.

14. Sarraf, C., Lalani, E-N, Golding, M., Anikumar, T. V., Poulsom, R. and Alison, M. 1994. Cell behavior in the acetylaminofluorene-treated regenerating rat liver. Am. J. Pathol. 145: 1114-1126.

15. Sells, M. A., Katyal, S. L., Shinozuka, H., Estes, L. W., Sell, S. and Lombardi, B. 1981. Isolation of oval cells and transitional cells from the livers of rats fed the carcinogen DL-ethionine. J. Natl. Cancer Inst. 66: 355-362.

16. Sell, S. and Dunsford, H. A. 1989. Evidence for the stem cell origin of hepatocellular carcinoma and cholangiocarcinoma. Am. J. Pathol. 134: 1347-1363.

17. Sirica, A. E. and Cihla, H. P. 1984. Isolation and partial characterizations of oval and hyperplastic bile ductular cellenriched populations from the livers of carcinogen and noncarcinogen-treated rats. Cancer Res. 44: 3454-3466.

18. Sirica, A. E., Mathis, G. A., Sano, N. and Elmore, L. W. 1990. Isolation, culture and transplantation of intrahepatic biliary epithelial cells and oval cells. Pathobiology 58: 4464.

19. Sonakul, D., Koompirochana, C., Chinda, K. and Stitnimakarn, T. 1978. Hepatic carcinoma with opisthorchiasis. Southeast Asian J. Trop. Med. Public Health 9: 215-219.

20. Steinberg, P., Steinbrecher, R., Radaeva, S., Schirmacher, P., Dienes, H. P., Oesch, F. and Bannasch, P. 1994. Oval cell lines OC/CDE 6 and OC/CDE 22 give rise to cholangiocellular and undifferentiated carcinomas after transformation. Lab. Invest. 71: 700-709.

21. Tsao, M. S. and Grisham, J. W. 1987. Hepatocarcinomas, cholangiocarcinomas and hepatoblastomas produced by chemically transformed cultured rat liver epithelial cells: a light and electron microscopic study. Am. J. Pathol. 127: 168-861.

22. Yaswen, P., Hayner, N. T. and Fausto, N. 1984. Isolation of oval cells by centrifugal elutriation and comparison with other cell types purified from normal and preneoplastic livers. Cancer Res. 44: 324-331.

23. Yoshimura, H., Harris, R., Yokoyama, S., Takahashi, S., Sells, M. A., Pan, S. F. and Lombardi, B. 1983. Anaplastic carcinoma in nude mice and in original donor strain rats inoculated with cultured oval cells. Am. J. Pathol. 110: 322-332. 